\title{
Market Structure And Banking Production Economies: Evidence From The 1980's Deregulation
}

\author{
Dr. Rasoul Rezvanian, Finance, Northeastern Illinois University \\ Dr. Nanda Rangan, Southern Illinois University \\ Dr. Richard Grabowski, Southern Illinois University
}

\begin{abstract}
This study examines the changes in the cost structure of banking firms using data from pre and post deregulation periods. A translog cost function is utilized for the analyses of economies of scale and scope. The results indicate that the average cost curves, although $U$-shaped flattened over time, resulting in an increase in optimal bank size. Economies of scope that existed prior to deregulation appears to be exhausted in a more nonconstrained environment.
\end{abstract}

\section{Introduction}

The banking industry has experienced considerable changes in recent years. The financial deregulation embodied in the Depository Institutions Deregulation and Monetary Control Act (DIDMCA) of 1980 and the Garn- St. Germain Act of 1982 has substantially altered the operations and financial services activities of the banking firm. The market structure has also undergone considerable changes with expanded powers for the thrift institutions, acquisitions by bank holding companies, and relaxation in state laws. The distinctions among depository institutions have blurred, resulting in greater competition among institutions.

There are three dimensions to the recent deregulation: price deregulation, product deregulation, and geographic deregulation. Price deregulation essentially eliminated the legal restrictions on the rates paid on both assets and liabilities of the banks' balance sheet. Product deregulation broadened the scope of activity of banks and other depository institutions in terms of the type of services they offer. The third dimension of deregulation--geographic--refers to the removal of limitations on interstate and intrastate banking. The above reforms are hypothesized to have influenced the cost structure of the banking industry. Specifically, the pricing limits on both the asset and liability side as well as the geographic limitations on bank expansion limited the extent to which banks could exploit economics of scale. As a result, one would expect that as these constraints are relaxed the optimal bank size would increase. Furthermore, the regulation on products that banks could provide limited the extent to which economies of cope could be exploited. Thus, the elimination of such limitations would allow banks to fully realize such economies from joint production and over time one would expect banks to exhaust these opportunities.

The purpose of this study is to test the hypothesis of structural change in the banking industry by estimating the scale and scope economies using data for the period prior to and after deregulation. Prior studies analyzing cost structure have generally used data either prior to or after deregulation, but very little attention has been devoted to analyzing the impact of deregulation by analyzing data both on a longitudinal and cross sectional basis. It is to this issue that this study will focus its attention.

\section{The Basic Model}

Banks typically produce multiple products. Hence, they can be regarded as multiproduct firms producing a vector of outputs from a vector of inputs. Invoking duality theory, the cost function dual to the production function may be expressed as

$$
\mathrm{C}\left(\mathrm{Y}_{1}, \ldots ., \mathrm{Y}_{\mathrm{n}} ; \mathrm{P}_{1}, \ldots ., \mathrm{P}_{\mathrm{m}}\right)=0
$$


where $P_{k}$ represent the price of inputs $x_{k}(k=1, \ldots, m)$, and $Y_{i}$ represent outputs $(i=1, \ldots, n)$. For the cost function (1), $C$ is increasing in $Y$ and $P$, is linearly homogenous and is concave in $\mathrm{P}$, and $\partial \mathrm{C} / \partial \mathrm{P}_{\mathrm{k}}=\mathrm{x}_{\mathrm{k}}$ (by Shepherd's Lemma).

Recent studies have used the flexible translog form for analyzing cost structure in banks. The translog function explicitly incorporates the multiproduct nature of the banking firm and does not require unnecessary prior restrictions. The translog cost function is a quadratic approximation to an arbitrary function of the form

$$
\text { Ln } C=f\left[\operatorname{Ln}\left(Y_{1}, \ldots, Y_{n} ; P_{1}, \ldots, P_{m}\right)\right]
$$

For a multiple output firm the function would take the form

$$
\begin{aligned}
& L n C=a_{0}+\sum_{k} b_{k} L n P_{k}+\sum_{i} a_{i} L n Y_{i}+1 / 2 \sum_{k} \sum_{1} g_{k I} L n P_{k} L n P_{1} \\
& +1 / 2 \sum_{i} \sum_{j} d_{i j} \operatorname{Ln} Y_{i} \operatorname{Ln} Y_{j}+\sum_{i} \sum_{k} f_{i k} \operatorname{Ln} Y_{i} \operatorname{Ln} P_{k^{\prime}}
\end{aligned}
$$

The translog function (3) will serve as the multiproduct cost function that will be estimated, where $b_{k}, a_{i}, g_{k l}, d_{i j}$ and $\mathrm{f}_{\mathrm{ik}}$ are the parameters of the cost function [the 1st and 2 nd order derivatives of $\operatorname{Ln~C]}$. Equation (3) has the following parameter restrictions:

(i) the cost function is linearly homogenous in input prices, which implies

$$
\sum_{k} b_{k}=1, \sum_{k} g_{k 1}=0 \text {, and } \sum_{k} f_{i k}=0 \text {, and, }
$$

(ii) second order approximation implies symmetry of the cross partial derivatives, i.e.,

$$
\mathrm{g}_{\mathrm{kl}}=\mathrm{g}_{\mathrm{k} k} \text {, and } \mathrm{d}_{\mathrm{ij}}=\mathrm{d}_{\mathrm{j}} \text {. }
$$

\section{Estimation Procedure}

The translog cost function (3) is linear in its unknown parameters, and hence amenable to ordinary least square (OLS) estimation. However, additional information is available, which can result in the improved efficiency of estimation (1). A set of factor demand equations can be derived from the joint cost function using Shepherd's Lemma. For the translog cost function (3) this yields the following $m$ equations:

$$
\partial L n C / \partial P_{k}=P_{k} X_{k} / C=S_{k}=b_{k}+\sum_{k} g_{k 1} L n P_{1}+\sum_{k} f_{i k} L n Y_{i} .
$$

where $s_{k}$ is the share of input $k$ in the total cost and where $\mathrm{k}=1, \ldots, \mathrm{m}$.

The translog cost function along with the $\mathrm{m}$ share equations comprise the cost system to be estimated. Since the coefficients in the share equations are a subset of those in the translog cost equation, the use of these share equations, in conjunction with the translog function, results in improved efficiency in estimation. However, since $\Sigma_{s_{k}}$ has to sum to unity, the share equations are not linearly independent. Any attempt to estimate the complete cost system will produce a singular covariance matrix of disturbances. This requires that one of the $m$ share equations be dropped to provide estimates of the complete cost system. Any share equation could be dropped because parameter estimates are independent [see Barten (1969)]. Efficient estimation is accomplished using Zellner's (1962) joint generalized least square (JGLS) for seemingly unrelated equations. This method is asymptotically equivalent to maximum likelihood estimation.

\section{Economies of Scale}

Scale economies for a multiproduct firm are measured along an expansion path where all outputs are increased in proportion. Following Bothwell and Cooley (1982) the appropriate measure of the overall scale economies for a multiproduct firm is the sum of the individual cost elasticities of each output. If we assume that all outputs are increased in proportion, i.e.,

$$
\frac{d Y_{i}}{Y_{i}}=d \operatorname{Ln} Y_{i}=\omega
$$

then the measure of scale economies (SE) is

$$
S E=\frac{d L n C}{\omega}=\sum_{i}\left(\frac{\partial \operatorname{LnC}}{\partial \operatorname{Ln} Y_{i}}\right)
$$

In terms of the translog function we have

$$
S E=\sum_{i}\left(\frac{\partial L n C}{\partial \operatorname{LnY} Y_{i}}\right)=\sum_{i} a_{i}+\sum_{i} \sum_{j} d_{i j} L n Y_{j}+\sum_{i} \sum_{k} f_{i k} L n P_{k} .
$$


The above procedure (i.e., differentiating the cost equation with respect to each output) will provide the cost elasticity for each output. The sum of the cost elasticities will be the measure of the overall economies of scale.

If $\mathrm{SE}$ is greater than 1, banking firms will experience decreasing returns to scale as costs rise proportionately more than output. A value for SE equal to 1 indicates constant returns to scale while a value less than 1 indicates increasing returns to scale.

\section{Economies of Scope}

The translog cost function is also be used to estimate scope economies from joint production or shared input costs of multiple outputs. To measure the extent of scope economies, Willig (1979) suggested the following measure for the case of two outputs:

$$
S C=\left[\frac{C\left(Y_{1}, 0\right)+C\left(0, Y_{2}\right)-C\left(Y_{1}, Y_{2}\right)}{C\left(Y_{1}, Y_{2}\right)}\right]
$$

Equation (10) implies that scope economies are present to the extent that the cost of separate production of $Y_{1}$ and $Y_{2}$ is greater than their joint production. Bank cost studies using this approach have found extremely large scope estimates which were not interpretable due to extrapolation. Alternatively, Kolari and Zardkoohi (1987) have proposed the following expression in an effort to avoid this extrapolation problem:

where

$$
\begin{gathered}
\Delta \mathrm{C}_{1}=\mathrm{C}\left(\mathrm{Y}_{1}^{\min }+\Delta \mathrm{Y}_{1}, \mathrm{Y}_{2}^{\min }\right)-\mathrm{C}\left(\mathrm{Y}_{1}^{\min }, \mathrm{Y}_{2}^{\min }\right) \\
S C=\frac{\Delta C_{1}+\Delta C_{2}-\Delta C_{1,2}}{\Delta C_{1,2}} \\
\Delta \mathrm{C}_{2}=\mathrm{C}\left(\mathrm{Y}_{1}^{\min } \mathrm{Y}_{2}^{\min }+\Delta \mathrm{Y}_{2}\right)-\mathrm{C}\left(\mathrm{Y}_{1}^{\min }, \mathrm{Y}_{2}^{\min }\right) \\
\Delta \mathrm{C}_{1,2}=\mathrm{C}\left(\mathrm{Y}_{1}^{\min }+\Delta \mathrm{Y}_{1}, \mathrm{Y}_{2}^{\min }+\Delta \mathrm{Y}_{2}\right)-\mathrm{C}\left(\mathrm{Y}_{1}^{\min }, \mathrm{Y}_{2}^{\min }\right)
\end{gathered}
$$

and superscripts denote the minimum output value in the sample. This measure utilizes the minimum output level for each product for banks and, therefore, mitigates the problem of distant extrapolation of the data beyond relevant output levels.

\section{Test of Production Technologies of the Banking Firms in the Pre and Post Deregulation Periods}

In order to evaluate the impact of deregulation on the production technologies of the banking firm, it is imperative to establish whether or not the cost structures prior to and after deregulation are the same.
Inability to establish any changes in the cost structure will imply that the deregulation had no effect on banking firms.

To test the null hypothesis that the cost functions are the same, a dummy variable $D$ is incorporated into the cost function to identify the individual banks. A value of zero is assigned for banks in the pre-regulation period and a value of one for banks in the post regulation period. Two models of the cost system are estimated-the unrestricted model incorporating the dummy variables and the restricted model wherein all dummy variable coefficients are equated to zero. A log likelihood ratio test is used to test the null hypothesis.

\section{Data}

Data for the study were gathered from the FDIC tapes on the Report of Income and Condition (call reports) for the years 1979, 1983, and 1987. Since there were two deregulatory acts in the 1980 s, the 1983 and 1987 data were selected to compare with pre-deregulation year 1979. A sample consisting of the same banks (1886) for each of the three sample years was drawn to provide a sample large enough for estimation and also to ensure a good representation of large banks. The data were not sub-sampled to reflect state laws regarding branching or holding company affiliation.

\section{Specification of Bank Costs, Outputs and Inputs}

Prior research in general appears to follow one of two approaches: the "intermediation approach" or the "production approach". According to the first approach, banks act as intermediaries in providing financial services. The outputs are measured in dollars and total cost includes both interest expense and total production costs. In contrast, the production approach views banks as producers of financial services, such as deposits and loans, by using capital and labor. Under this approach interest costs are not included in total cost and outputs are measured as the number of accounts serviced.

This study uses the intermediation approach and, hence, interest costs are included in the total costs. Further, outputs are measured in thousands of dollars, as opposed to number of accounts (2). The cost and output measures for the year 1983 and 1987 are adjusted so that all the variables are measured in constant dollars with 1979 as the base year.

The inputs used in the calculation of the various efficiency measures are: labor $\left(\mathrm{x}_{1}\right)$, capital $\left(\mathrm{x}_{2}\right)$, and loanable funds $\left(x_{3}\right)$. Labor is measured by the number of full-time employees on the payroll at the end of the 
time period and capital by the book value of premises and fixed assets. Loanable funds include time deposits and other loanable funds Federal funds purchased and securities sold under agreement to repurchase, demand notes issued to the U.S. Treasury, and other borrowed money. Capital and loanable funds are measured in thousands of dollars.

Five outputs, all measured in thousands of dollars, are used: real estate loans $\left(Y_{1}\right)$, commercial and industrial loans $\left(\mathrm{Y}_{2}\right)$, consumer loans $\left(\mathrm{Y}_{3}\right)$, demand deposits $\left(\mathrm{Y}_{4}\right)$ and securities $\left(\mathrm{Y}_{5}\right)$.

\section{Empirical Results}

The cost system comprising the translog cost function (3) and the cost share equations (6) was estimated using Zellner's (1962) seemingly unrelated regressions method. The result of the estimation for the pre-deregulation (1979) and post-deregulation $(1983,1987)$ years are presented in Table 1 (3). These results were obtained by dropping the capital share equation and by imposing symmetry and input price homogeneity. All models had an R-square value equal to 0.95 and most of the parameters were significant at the $1 \%$ level.

In order to determine whether or not the cost functions were the same in 1987 and 1983 as in 1979, dummy variables were used. Specifically, each variable and the intercept in the translog cost function (3) and the cost share equation (6) was multiplied by a dummy and added to the original variables in the cost and share equations (3) and (6). The dummy variables take on a value of zero in 1979 and one in 1987. This system was again estimated using the seemingly unrelated regression method. The likelihood ratio test was then used to determine whether the coefficients for the dummy variables were significantly different from zero. Table 2 presents the results for the tests of equality of cost functions.

The test results indicated that the coefficients of the dummy variables were significantly different from zero. A second set of equations was also estimated in which all variables excluding the intercept were multiplied by a dummy variable and added to the variables in the original cost and share equations. The likelihood ratio test again indicated that the coefficients for the dummy variables were significantly different form zero. Thus the cost function for 1979 and 1987 differ by more than just the intercept. The tests were repeated for 1979 and 1983. These results also indicate that the cost functions differ between 1979 and 1983.

The coefficients for the translog cost functions report- ed in Table 1 were used to calculate the scale elasticity for each observation in the data set. The mean values of the scale elasticities for eight different size categories for years 1979, 1983, and 1987 are presented in Table 3. The results suggest that the cost curves are U-shaped with varying flatness at the tails. Table 3 indicates significant scale economies for all sizes up to $\$ 100$ million deposits, and significant diseconomies of scale for banks beyond $\$ 200$ million in total deposits. Similar pattern exists for the year just after deregulation (1983). Examination of the estimates of scale economies for the year 1987 reveal different results. It appears that the optimal size of banks increased by 1987 to $\$ 200-\$ 400$ million size group.

Table 4 presents the mean values of the economies of scope measure for the eight different size categories for 1979, 1983, and 1987 (4). The results indicate that there were cost advantage associated with joint production of outputs for all size categories, except the smallest, in 1979. However, the potential economies of scope were exhausted for all sizes except for medium sized banks in 1983. Almost the same pattern follows for 1987 except that economies of scope were detected for the very smallest banks. Thus, after deregulation, economies of scope seem to have been exhausted, especially for the larger banks (5).

\section{Summary and Conclusions}

In this paper it was argued that regulations limiting price as well as those limiting geographic expansion limited the extent to which banks could exploit scale economies. Thus it was hypothesized that the elimination of such regulations would result in an increase in the optimal scale of bank operations. In addition, limitations on product diversity prevented banking firms from exploiting economies of scope. Thus, if it was hypothesized that prior to deregulation one would expect to find such economies in existence. Alternatively after deregulation one would expect banks to have exhausted these possibilities.

In order to test these hypotheses, a translog cost function was utilized to analyze the cost structure for a sample of banks prior to and after deregulation. Specifically, a translog cost function were estimated for 1979, 1983, and 1987 and measures of scale elasticity and economies of scope constructed. The results indicated that the cost functions for all three years were statistically different. In addition, examination of scale economies for the period under consideration reveals that the cost curves were U-shaped in all the three years under study. The average cost curves flattened over 
Table 1

Estimates of the Cost Function for 1979,83 and $87^{\circ}$

1979

Par.

Est.

Std.

Coef.

3.790

$a_{0}$

$b_{1}$

$b_{2}$

$b_{3}$

$a_{1}$

$a_{2}$

$a_{3}$

$a_{4}$

$a_{5}$

$g_{11}$

$g_{22}$

$g_{33}$

$g_{12}$

$\mathrm{g}_{13}$

$g_{23}$

$d_{11}$

$d_{22}$

$d_{33}$

$d_{44}$

$d_{55}$

$d_{12}$

$d_{13}$

$d_{14}$

$d_{23}$

$d_{24}$

$d_{25}$

$d_{34}$

$d_{35}$

$d_{45}$

$f_{11}$

$f_{12}$

$f_{13}$

$f_{14}$

$f_{15}$

$f_{21}$

$f_{23}$

$\mathrm{f}_{24}$

$\mathrm{f}_{25}$

$f_{31}$

$f_{32}$

$f_{33}$

$f_{34}$

$3.790^{*}$

$-0.146^{*}$

$0.061^{*}$

$1.084^{*}$

$0.224^{*}$

0.324 *

$-0.023^{*}$

$-0.361^{*}$

$0.338^{*}$

$0.082^{*}$

$0.014^{*}$

$0.089^{*}$

$-0.003^{*}$

$-0.080^{*}$

$-0.010^{*}$

$0.102^{*}$

$0.057^{*}$

$0.108^{*}$

$0.055^{*}$

$0.149^{*}$

$-0.015^{*}$

$-0.011$

$-0.039^{*}$

$-0.025^{*}$

$-0.034^{*}$

0.001

$-0.011$

0.006

$-0.050^{*}$

$-0.030$

$-0.016^{*}$

$-0.018^{*}$

$0.010^{\prime \prime}$

$-0.065^{*}$

$-0.001$

0.001

0.006

$0.022^{*}$

$-0.028$

$0.017^{*}$

$0.018^{*}$

$-0.017^{*}$

$-0.010^{*}$

$0.092^{*}$
1983

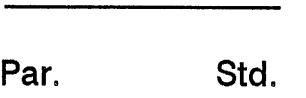

Est. Error
1987
Est. Std. $\quad$ Ear.

0.170

$\begin{array}{rrrrl}4.362^{*} & 0.157 & 4.427^{*} & 0.170 & \text { Interc. } \\ -0.145^{*} & 0.021 & -0.238^{*} & 0.030 & \operatorname{LnP}{ }_{1} \\ 0.033^{*} & 0.008 & 0.048^{*} & 0.011 & \operatorname{LnP}_{2} \\ 1.113^{*} & 0.025 & 1.189^{*} & 0.034 & \operatorname{LnP}_{3}\end{array}$

$1.113^{*} \quad 0.025$

$0.060 * \quad 0.038$

$\begin{array}{ll}0.286^{*} & 0.037 \\ 0.080^{*} & 0.045\end{array}$

$1.189^{*}$

$0.086^{*}$

$0.232^{*}$

$0.080^{*} \quad 0.045$

$\begin{array}{ll}-0.224^{*} & 0.063\end{array}$

$0.273^{*} \quad 0.045$

$0.073^{*} \quad 0.004$

$0.013^{*} \quad 0.001$

$0.093^{*} \quad 0.005$

$0.003^{*} \quad 0.001$

$\begin{array}{ll}-0.076^{*} & 0.004 \\ -0.016 & 0.002\end{array}$

$-0.016^{*} \quad 0.002$
0.081

$0.081^{*} \quad 0.006$

$0.056^{*} \quad 0.005$

$0.070^{*} \quad 0.010$

0.019 * $\quad 0.023$

$0.171^{*} \quad 0.009$

$\begin{array}{cc}-0.035^{*} & 0.006 \\ 0.001 & 0.007\end{array}$

$0.001 \quad 0.007$

$\begin{array}{ll}-0.002 & 0.009\end{array}$

$-0.026^{*}$

0.007

0.006

0.010

0.006

0.011

0.008

0.012

0.001

0.001

0.001

0.002

0.001

0.001

0.001

0.001

0.001

0.001

0.001

0.001

0.002

0.003

0.002
0.007

$-0.056$

$0.296^{*}$

$0.088^{*}$

$0.014^{*}$

$-0.002$

$-0.086^{*}$

$-0.012^{*}$

$0.121^{*}$

$0.056^{*}$

$0.060^{*}$

$0.083^{*}$

$0.124^{*}$

$-0.024^{*}$

$-0.029^{*}$

$-0.100$

$-0.035^{*}$

$-0.006$

$-0.039^{*}$

$0.010^{*}$

$0.023^{*}$

$-0.330^{*}$

$-0.058^{*}$

$-0.012^{*}$

$-0.008^{*}$

$0.005^{*}$

$0.037^{*}$

$-0.025^{*}$

$-0.001$

0.001

0.001

$0.018^{*}$

$-0.015^{*}$

$0.013^{*}$

$0.008^{*}$

$-0.004^{*}$

$-0.055^{*}$

$0.040^{*}$
0.034

0.042

0.037

0.040

0.060

0.036

0.005

0.001

0.006

0.001

0.005

0.002

0.009

0.005

0.007

0.012

0.005

0.006

0.007

0.010

0.006

0.006

0.008

0.005

0.009

0.007

0.008

0.001

0.001

0.002

0.002

0.001

0.001

0.001

0.001

0.001

0.001

0.002

0.001

0.002

0.003

0.001
$\operatorname{LnP}_{3}$

LnY

$\operatorname{LnY} Y_{2}$

$\operatorname{LnY}_{3}$

$\operatorname{LnY}_{4}$

$\operatorname{LnY} Y_{5}$

$\left.(\operatorname{LnP})_{1}\right)^{2}$

$\left(\mathrm{LnP}_{2}\right)^{2}$

$\left(\mathrm{LnP}_{3}\right)^{2}$

$\operatorname{Ln} P_{1}{ }^{*} \operatorname{LnP} P_{2}$

$\mathrm{LnP}_{1}{ }^{*} \operatorname{LnP}_{3}$

$\operatorname{LnP}_{2}{ }^{*} \operatorname{LnP} P_{3}$

$\left.(\operatorname{LnY})_{1}\right)^{2}$

$\left(\operatorname{LnY} Y_{2}\right)^{2}$

$\left(\operatorname{Ln} Y_{3}\right)^{2}$

$\left(\operatorname{LnY} Y_{4}\right)^{2}$

$\left(\operatorname{LnY} Y_{5}\right)^{2}$

$\operatorname{Ln} Y_{1}{ }^{*} \operatorname{Ln} Y_{2}$

$\operatorname{Ln} Y_{1}{ }^{*} \operatorname{Ln} Y_{3}$

$\operatorname{Ln} Y_{1}{ }^{*} \operatorname{Ln} Y_{4}$

$\operatorname{LnY_{1}}{ }^{*} \operatorname{Ln} Y_{5}$

$\operatorname{Ln} Y_{2}{ }^{*} \operatorname{Ln} Y_{3}$

$\operatorname{LnY}{ }_{2}^{*} \operatorname{Ln} Y_{4}$

$\operatorname{Ln} Y_{2}{ }^{*} \operatorname{Ln} Y_{5}$

$\operatorname{Ln} Y_{3}{ }^{*} \operatorname{Ln} Y_{4}$

$\operatorname{Ln} Y_{3}{ }^{*} \operatorname{Ln} Y_{5}$

$\operatorname{Ln} Y_{4}{ }^{*} \operatorname{Ln} Y_{5}$

$\operatorname{LnP}_{1}{ }^{*} \operatorname{Ln} Y_{1}$

$\operatorname{LnP}{ }_{1}^{*} \operatorname{Ln} Y_{2}$

$\operatorname{LnP}{ }_{1}^{*} \operatorname{LnY} Y_{3}$

$\operatorname{LnP}{ }_{1}{ }^{\star} \operatorname{Ln} Y_{4}$

$\operatorname{Ln} P_{1}{ }^{*} \operatorname{Ln} Y_{5}$

$\operatorname{LnP} P_{2}^{*} \operatorname{Ln} Y_{1}$

$\operatorname{LnP}_{2}{ }^{*} \operatorname{Ln} Y_{2}$

$\operatorname{LnP}{ }_{2}^{*} \operatorname{Ln} Y_{3}$

$\operatorname{LnP}_{2}{ }^{*} \operatorname{Ln} Y_{4}$

$\operatorname{LnP}_{2}{ }^{*} \operatorname{Ln} Y_{5}$

$\operatorname{Ln} P_{3} * \operatorname{Ln} Y_{1}$

$\operatorname{LnP}_{3}{ }^{*} \operatorname{LnY} Y_{2}$

$\operatorname{LnP}_{3}{ }^{*} \operatorname{LnY} Y_{3}$

$\operatorname{LnP}_{3} * \operatorname{Ln} Y_{4}$

$\operatorname{LnP}_{3} * \operatorname{Ln} Y_{5}$

$\begin{array}{lll}\text { Adj } & \mathrm{R}^{2} & 0.95\end{array}$ 0.95

0.95

${ }^{a}$ Asterisks indicate significant at the 0.001 level. 
TABLE 2

Log Likelihood Ratio (LR) Tests for the Equality

of Cost Functions for the years 1979 Versus 1983 and for the years 1979 Versus 1987

\begin{tabular}{|c|c|c|c|}
\hline $\begin{array}{l}\text { Cost Function } \\
\text { Comparison }\end{array}$ & $\begin{array}{l}\text { Determinant } \\
\text { of Disturbance } \\
\text { Covariance } \\
\text { Matrix }\end{array}$ & $\begin{array}{c}\text { Test } \\
\text { Statistic }\end{array}$ & $\begin{array}{c}\text { Degrees of } \\
\text { Freedom }\end{array}$ \\
\hline $\begin{array}{l}1979 \text { versus } 1983 \\
\text { Unrestricted } \\
\text { Model } \\
\text { Restricted } \\
\text { Model }\end{array}$ & $2.0249 \times 10^{-7}$ & & \\
\hline $\begin{array}{l}\mathrm{Da}_{0}=\ldots \ldots=\mathrm{Df}_{35}=0 \\
\mathrm{Db}_{1}=\ldots \ldots=\mathrm{Df}_{35}=0\end{array}$ & $\begin{array}{l}2.2522 \times 10^{-7} \\
2.2134 \times 10^{-7}\end{array}$ & $\begin{array}{l}401^{*} \\
335^{*}\end{array}$ & $\begin{array}{l}38 \\
37\end{array}$ \\
\hline $\begin{array}{l}1979 \text { versus } 1987 \\
\text { Unrestricted } \\
\text { Model } \\
\text { Restricted } \\
\text { Model }\end{array}$ & $2.03112 \times 10^{-7}$ & & \\
\hline $\begin{array}{l}\mathrm{Da}_{0}=\ldots \ldots=\mathrm{Df}_{35}=0 \\
\mathrm{Db}_{1}=\ldots \ldots=\mathrm{Df}_{35}=0\end{array}$ & $\begin{array}{l}2.16212 \times 10^{-7} \\
2.09198 \times 10^{-7}\end{array}$ & $\begin{array}{l}235^{*} \\
111^{*}\end{array}$ & $\begin{array}{l}38 \\
37\end{array}$ \\
\hline
\end{tabular}

"Statistically significant at 0.005 level of significance

time, resulting in an increase in optimal bank size. Finally, our results show that although there were significant cost complementarities in the production process during 1979, they do not exist in the more unconstrained environment of 1983 and 1987.

The empirical results of this paper are consistent with the results of Le Compte and Smith (1990) using S\&L data for years 1979 and 1983. The authors believe that these results reflect the removal of regulatory barriers on both the assets and liabilities. However, there are other factors, such as technology, and high and volatile that affect the scale economies [see Hunter and Timme (1986) and Humphrey (1987)]. Due to some level of confounding, caution must be exercised in interpreting these results as all of the changes over time cannot be attributed to deregulation alone.

\section{Suggestions for Future Research}

Translog cost function approaches to the study of banking performance suffer form one major shortcoming; they represent an average rather than frontier function approach. It would seem that if one is inter- ested in performance, frontier cost and production methodologies for constructing cost and production frontiers can be modified to take into account technical innovation and economies of scope. Thus, one could derive measures of both, as well as measures of efficiency performance, for long periods of time. In addition, one could apply the same methodologies to other sets of financial institutions to analyze the effects of deregulation, mergers, etc.

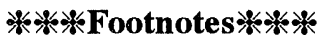

1. Using factor share equations has increased the number of degrees of freedom in studies in which the number of observations has been relatively small. In our study a fairly large sample size is used such that degrees of freedom are not a major concern.

2. Berger, Hanweck, and Humphrey (1987) and Kolari and Zardkoohi (1987) make a distinction between the physical production of numbers of accounts and the financial production of dollars of intermediation services. 


\section{TABLE 3}

Economies of Scale for the Years 1979, 1983 and 1987 (standard error in parentheses)

\begin{tabular}{|c|c|c|c|c|c|c|}
\hline \multirow{2}{*}{$\begin{array}{l}\text { Deposit } \\
\text { Size Group } \\
\text { (\$ mills) }\end{array}$} & \multicolumn{3}{|c|}{ Sample Size } & \multicolumn{3}{|c|}{ Economies of Scale } \\
\hline & 1979 & 1983 & 1987 & 1979 & 1983 & 1987 \\
\hline $0-25$ & 1012 & 972 & 854 & $\begin{array}{c}0.864^{*} \\
(0.005)\end{array}$ & $\begin{array}{c}0.867^{*} \\
(0.005)\end{array}$ & $\begin{array}{c}0.857^{*} \\
(0.005)\end{array}$ \\
\hline 25- 50 & 425 & 466 & 497 & $\begin{array}{c}0.929^{*} \\
(0.003)\end{array}$ & $\begin{array}{c}0.927^{*} \\
(0.003)\end{array}$ & $\begin{array}{c}0.905^{*} \\
(0.004)\end{array}$ \\
\hline $50-100$ & 280 & 250 & 269 & $\begin{array}{c}0.969^{*} \\
(0.004)\end{array}$ & $\begin{array}{c}0.964^{*} \\
(0.004)\end{array}$ & $\begin{array}{c}0.935^{*} \\
(0.003)\end{array}$ \\
\hline $100-200$ & 85 & 100 & 128 & $\begin{array}{c}1.002 \\
(0.005)\end{array}$ & $\begin{array}{c}0.998 \\
(0.005)\end{array}$ & $\begin{array}{c}0.961^{*} \\
(0.004)\end{array}$ \\
\hline 200- 400 & 44 & 50 & 58 & $\begin{array}{c}1.034^{*} \\
(0.007)\end{array}$ & $\begin{array}{c}1.032^{*} \\
(0.007)\end{array}$ & $\begin{array}{c}0.989 \\
(0.006)\end{array}$ \\
\hline $400-700$ & 20 & 21 & 26 & $\begin{array}{c}1.069^{*} \\
(0.009)\end{array}$ & $\begin{array}{c}1.054^{*} \\
(0.008)\end{array}$ & $\begin{array}{c}1.016 * \\
(0.007)\end{array}$ \\
\hline $700-1000$ & 4 & 11 & 13 & $\begin{array}{c}1.097^{*} \\
(0.010)\end{array}$ & $\begin{array}{c}1.070^{*} \\
(0.009)\end{array}$ & $\begin{array}{c}1.026^{*} \\
(0.008)\end{array}$ \\
\hline$>1000$ & 16 & 16 & 23 & $\begin{array}{c}1.129^{*} \\
(0.013)\end{array}$ & $\begin{array}{c}1.135^{*} \\
(0.012)\end{array}$ & $\begin{array}{c}1.078^{*} \\
(0.011)\end{array}$ \\
\hline
\end{tabular}

* Scale economies statistically different from unity at the 0.001 level of significance.

3. To determine whether the translog functional form is a statistically significant improvement over models used in prior studies, structural tests were conducted to examine both whether the bank production process was characterized by constant return to scale and if the production process was separable. Both hypotheses were decisively rejected at 0.05 level of significant.

4. For cost complementarities to exist, theory suggests that there be non-negative marginal costs and that the output intersection terms have negative signs (i.e., cost declines with joint production). It should be noted that inferences concerning scope economies based on model coefficients are general in nature because all of the sample observations are being used, whereas the scope economies shown in table 3 are calculated for sub-samples of banks in specific size range.

5. We do not calculate the possibility of any pairs of cost complementarities between any pairs of 
TABLE 4

Economies of Scope for the Years 1979, 1983, and 1987 (Deflated 1979=100)

\begin{tabular}{lcccccc}
\hline $\begin{array}{l}\text { Deposit } \\
\text { Size Group } \\
\text { (\$millions) }\end{array}$ & \multicolumn{3}{c}{ Sample Size } & & \multicolumn{3}{c}{ Economies of Scope } \\
\cline { 2 - 6 } \cline { 5 - 7 } & 1979 & 1983 & 1987 & 1979 & 1983 & 1987 \\
\hline $0-25$ & 1012 & 972 & 854 & -0.105 & -0.067 & 0.024 \\
$25-50$ & 425 & 466 & 497 & 0.179 & -0.093 & -0.187 \\
$50-100$ & 280 & 250 & 269 & 0.417 & 0.152 & -0.267 \\
$100-200$ & 85 & 100 & 128 & 0.157 & 0.102 & -0.308 \\
$200-400$ & 44 & 50 & 58 & 0.800 & 0.052 & -0.339 \\
$400-700$ & 20 & 21 & 26 & 0.214 & -0.137 & -0.395 \\
$700-1000$ & 4 & 11 & 13 & 0.128 & -0.433 & -0.336 \\
$>1000$ & 16 & 16 & 23 & 0.018 & -0.226 & -0.239 \\
& & & & & & \\
\hline
\end{tabular}

outputs because our interest is in the global economies of scope estimation.

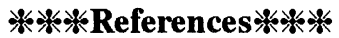

1. Barten A.P., "Maximum likelihood estimation of a complete system of demand equations," European Economic Review, Sept.-Dec. pp. 778.1969

2. Bothwell, J.L. and T.F. Cooley,, Efficiency in the provision of health care: An analysis of health maintenance organizations, Southern Economic Journal 4, pp. 970-984 1982.

3. Humphrey, D.B., "Cost Dispersion and the Measurement of Economies in Banking", Economic Review, May, June, Federal Reserve Bank of Richmond, pp. 24-38, 1987.

4. Hunter W. C., and S. G. Timme, "Technical Change, Organizational Form, and the Structure of Bank Production," Journal of Money Credit and Banking, pp. 153-166, 1986.
5. Kolari, J.M. and A. Zardkoohi, "Bank costs, structure, and performance," Lexington D.C. Health and Company, 1987.

6. Le Compte L.B., and S.D. Smith, "Changes in the cost of intermediation: The case of Saving and Loans," Journal of Finance, 1337-1346, 1990.

7. Willig, R., "Multiproduct technology and market structure," American Economic Review, 69, 346351, 1979.

8. Zellner, A., "An efficient method for estimating seemingly unrelated regressions and tests for aggregation bias," Journal of American Statistical Association, June, pp. 582-612, 1962. 